\title{
Maxillary Sinus Cancer pT3 TNM Finding v8
}

National Cancer Institute

\section{Source}

National Cancer Institute. Maxillary Sinus CancerpT3 TNM Finding v8. NCI Thesaurus.

Code C133037.

Maxillary sinus cancer with tumor invading any of the following: bone of the posterior wall of maxillary sinus, subcutaneous tissues, floor or medial wall of orbit, pterygoid fossa, or ethmoid sinuses. (from AJCC 8th Ed.) 